\title{
Assessment of intensity of posttraumatic stress symptoms in parents of children with blood cancer at different time points following diagnosis
}

\author{
Ocena nasilenia stresu potraumatycznego u rodziców dzieci z nowotworami krwi \\ w zależności od momentu postawienia diagnozy \\ 'Chair of Sociology, Psychology and Communication in Management, Faculty of Management, Czestochowa University of Technology, Częstochowa, Poland \\ ${ }^{2}$ Department of Child and Adolescent Psychiatry, Medical University of Lodz, Kódź, Poland \\ Correspondence: Ewelina Chrapek, Chair of Sociology, Psychology and Communication in Management, Faculty of Management, Czestochowa University of Technology, \\ Armii Krajowej 19B, 42-200 Częstochowa, Poland, e-mail: ewelinachrapek@wp.pl
}

\begin{abstract}
In the recent years, there has been a remarkable progress in treatment of cancer in children. Nevertheless, it still remains a disease that represents a real threat to a child's life. This threat as well as a deep fear for a child's life which is strongly associated with it have a key impact on psychological difficulties experienced by parents at the time of establishing their child's diagnosis and throughout therapy. Aim: The study was focused on assessment of the dynamics of posttraumatic symptoms intensity in parents of children suffering from blood cancers depending on a period of time that passed since the moment the disease was diagnosed. Materials and methods: A prospective study model was applied - the parents were assessed at three time points, i.e. up to one month (t1), six months ( $\mathrm{t} 2$ ) and one year ( $\mathrm{t} 3$ ) following their child's diagnosis. The study included 47 parents of children diagnosed with leukaemia or lymphoma. The number of the subjects taking part in successive measurements was $32(\mathrm{t} 2)$ and $31(\mathrm{t} 3)$, respectively. The Impact of Event Scale - Revised (IES-R) was used to assess severity of posttraumatic stress symptoms in the parents. Results: Severity of posttraumatic stress symptoms in the parents decreased within one year following their child's diagnosis. An analysis of intensity of particular dimensions of posttraumatic stress at the successive time points revealed their variability. The level of symptoms related to avoidance did not decrease significantly in the period between one and six months following the diagnosis, or between six months and one year following the diagnosis. Conclusions: The study results provide grounds for putting forward of recommendations concerning diagnostic and therapeutic measures. At the time of diagnosis, parents should be provided with special psychological intervention, whereas, at next stages of a child's treatment, therapists should focus their attention mostly on avoidance symptoms and the role they play in the process of parents' adaptation to their child's illness.
\end{abstract}

Keywords: parents of paediatric cancer patients, posttraumatic stress, intrusion, hyperarousal, avoidance, adaptation

Streszczenie W ciągu ostatnich lat dokonał się znaczący postęp w leczeniu chorób nowotworowych u dzieci. Mimo tego wciąż są to choroby, które niosą ze sobą realne niebezpieczeństwo utraty życia dziecka. To niebezpieczeństwo i związany z nim silny lęk o życie dziecka mają kluczowe znaczenie dla trudności psychologicznych przeżywanych przez rodziców w momencie diagnozy dziecka oraz w przebiegu jego leczenia. Cel: Celem badania była ocena dynamiki nasilenia objawów stresu potraumatycznego u rodziców dzieci z chorobami nowotworowymi krwi w zależności od czasu, jaki upłynął od momentu diagnozy dziecka. Materiał i metody: Zastosowano prospektywny model badania: rodzice badani byli w trzech punktach czasowych: do miesiąca (t1), pół roku (t2) oraz rok (t3) od momentu diagnozy dziecka. W badaniu udział wzięło 47 rodziców dzieci z diagnozą białaczki lub chłoniaka. W kolejnych pomiarach liczba uczestniczących rodziców wynosiła odpowiednio $\mathrm{t} 2$ - 32, t3 - 31. Do oceny nasilenia objawów stresu potraumatycznego u rodziców zastosowano Zrewidowaną Skalę Wpływu Zdarzeń (Impact of Event Scale - Revised, IES-R). Wyniki: Nasilenie objawów stresu potraumatycznego u rodziców zmniejszyło się w okresie roku od momentu diagnozy dziecka. Analiza nasilenia poszczególnych wymiarów stresu potraumatycznego w kolejnych punktach czasowych wykazała ich zmienność. Poziom objawów wymiaru unikania nie zmniejszył się istotnie między okresem do miesiąca i pół roku od diagnozy, a także między okresem pół roku i roku od diagnozy. Wnioski: Wyniki badania dają podstawę do sformułowania zaleceń służących oddziaływaniom 
diagnostyczno-terapeutycznym. W okresie diagnozy rodzice powinni być objęci szczególną interwencją psychologiczną, natomiast w kolejnych etapach leczenia dziecka uwaga terapeutów powinna być skupiona zwłaszcza na objawach unikania oraz roli, jaką odgrywają oni w procesie adaptacji rodziców do choroby dziecka.

Słowa kluczowe: rodzice dzieci chorych na nowotwór, stres potraumatyczny, intruzja, pobudzenie, unikanie, adaptacja

\section{INTRODUCTION}

$\longrightarrow$ hildren are affected by cancer definitely less frequently than adults, accounting for $1 \%$ of all cancer cases in the Polish population (Meder, 2014). It is the second-leading cause of death among children and adolescents aged 1-19 years, after accidents, injury and poisoning episodes (Szymborski et al., 2014). The most common types of cancer of the developmental age are hematopoietic system diseases with leukaemia cases accounting for $30-35 \%$ of all diagnosed cancer conditions, and lymphoma cases accounting for 8-10\% (Krawczuk-Rybak, 2011; Stolarska i Młynarski, 2011).

Despite the recently observed progress in the efficacy of cancer therapy focused on patients in the development stage, and consequently, better prognosis and a higher survival rate, the disease still poses a real threat to a child's life (Balcerska et al., 2008; Kowalczyk, 2008). Health condition of a young patient, and particularly the threat of death, the sense of unpredictability of events and loss of control create a risk of serious difficulties in a child's emotional functioning (Deręgowska, 2010). Such consequences also affect family members of a young patient (Solecka, 2007). Stressors experienced by parents of a child suffering from cancer are not only associated with the fear for the young patient's life but also with his/her intensive therapy and its side effects, the child's suffering, frequent hospital stays, financial problems and destabilized functioning of the whole family. Numerous research studies confirm that parents taking care of children with cancer develop psychopathological symptoms (Vrijmoet-Wiersma et al., 2008).

Psychological consequences of cancer-related experiences are often categorised as post-traumatic stress. There occur characteristic posttraumatic stress symptoms that may be observed in parents of children with cancer, such as intrusive thoughts related to the disease, avoidance response, autonomic arousal, sleep disorders or concentration difficulties (Baran, 2009). As a result of cancer-related experience, both young patients and their family members may develop full-blown posttraumatic stress disorder syndrome (PTSD) or a milder normative response not meeting the criteria of the syndrome defined as "subclinical posttraumatic stress symptoms" (PTSS) (Stuber et al., 2003). Empirical data confirm occurrence of PTSD and PTSS in the group of parents of cancer children, however, various research studies report different percentage rates of parents presenting the problems (Kazak et al., 2004, 2005; Landolt et al., 2003). These differences may re- was taken since studies indicate gradual alleviation of stress symptoms over time that passed following diagnosis (Cernvall et al., 2012; Jurbergs et al., 2009; Landolt et al., 2012; Pöder et al., 2008; Rodriguez et al., 2012). Parents of young patients who have just been diagnosed present more severe posttraumatic symptoms than those whose children have already completed therapy (Phipps et al., 2005). Research data show that intensity of these symptoms reaches its highest level at the point of hearing the diagnosis. Two weeks after diagnosis, $51 \%$ of mothers and $40 \%$ of fathers met the diagnostic criteria of acute stress disorder (ASD), i.e. a response lasting shorter time than PTSD and is accompanied by characteristic dissociative symptoms (Patiño-Fernández et al., 2008). In other studies, a week after diagnosis, the percentage rate of parents meeting the criteria was 33\% (Pöder et al., 2008). Measurements taken after one week (t1), two months (t2) and four months (t3) following diagnosis, the percentage rate for clinical value of the symptoms indicating a risk of developing PTSD was $\mathrm{t} 1-43,21, \mathrm{t} 2-33,19, \mathrm{t} 3-$ 28, 7 in mothers and fathers, respectively (Cernvall et al., 2012). Data based on measurements taken approximately six months following diagnosis revealed that $51.5 \%$ of mothers and $40.4 \%$ of fathers of young patients fulfilled the criteria of PTSD, whereas, a year after the diagnosis those figures were $25.4 \%$ and $18.4 \%$, respectively (Landolt et al., 2012). As the research studies prove, symptoms of posttraumatic stress decrease with time that passed since the moment of diagnosis, although, in some parents a higher level of symptoms may persist even after completion of therapy (Norberg et al., 2005). Additionally, intensity of specific posttraumatic stress dimensions may change depending on a stage of a child's therapy. Therefore, it seems important not only to define the dynamics of general posttraumatic stress in parents but also to differentiate intensity of specific posttraumatic stress symptoms. Polish literature still lacks a sufficient number of studies that could thoroughly reflect the analysed issue. Thus, this article is an attempt to find an answer to the question on how intensity of posttraumatic stress and its specific symptoms change in parents of a child suffering from blood cancer depending on time that passed since the child's diagnosis. It is crucial not only in the context of providing parents with effective support but also in the context of functioning of a child affected by the disease. The literature on the subject clearly emphasizes the important relationship between parents' and their child's adaptation to the disease (Fisak and Grills-Taquechel, 2007; Garber and Cole, 2010; Steele et al., 2004). 


\section{MATERIALS AND METHODS}

Since statistically, haematopoietic system cancers represent the most common type of cancer of the development stage, parents of children with diagnosed leukaemia or lymphoma were qualified for the study only. They were asked to take part in the study during their children's stay at the Department of Paediatrics, Oncology and Haematology of Young Children and Adolescents or at the Department of One-Day Haematological Oncology Therapy for Children of the Central Teaching Hospital, Medical University of Lodz (successive stages of the study). Candidates were informed on the aim, procedure and conditions of the study. Persons who were willing to join the study had to give their written consent by filling out a relevant form. The study was conducted at three time points, i.e. $\mathrm{t} 1$ - within one month following diagnosis, $\mathrm{t} 2$ - six months following diagnosis and $\mathrm{t} 3$ one year following diagnosis. Among the parents who met the criteria and were qualified for the study, 88 individuals (mothers or fathers of a particular child) gave their informed consent. Due to withdrawal from participation in the study (25 parents), death of a child (four parents) or loss of contact, the first stage of the study (t1) ultimately included 47 parents. Due to withdrawal from the study (12 parents) and loss of contact (three parents), 32 parents were qualified for the second stage ( $\mathrm{t} 2)$. Whereas, the third stage ( $\mathrm{t} 3$ ) included 31 parents (one parent was excluded due to death of the child). Parents most frequently refused to take part in the study because of lack of time resulting

\begin{tabular}{|c|c|c|c|}
\hline & & $n$ & $\%$ \\
\hline \multirow{2}{*}{ Parent's sex } & Females & 37 & 78.7 \\
\hline & Males & 10 & 21.3 \\
\hline & & $M$ & SD \\
\hline \multicolumn{2}{|l|}{ Parent's age [years] } & 37.7 & 7.0 \\
\hline & & $n$ & $\%$ \\
\hline \multirow{2}{*}{ Place of residence } & Urban area & 26 & 55.3 \\
\hline & Rural area & 21 & 44.7 \\
\hline \multirow{4}{*}{ Education } & Basic vocational & 5 & 10.6 \\
\hline & Secondary level & 19 & 40.5 \\
\hline & Incomplete higher level & 5 & 10.6 \\
\hline & Higher level & 18 & 38.3 \\
\hline \multirow{2}{*}{ Child's sex } & Girls & 26 & 55.3 \\
\hline & Boys & 21 & 44.7 \\
\hline & & $M$ & SD \\
\hline \multirow{2}{*}{\multicolumn{2}{|c|}{ Child's age [years] }} & 7.8 & 4.8 \\
\hline & & $n$ & $\%$ \\
\hline \multirow{4}{*}{ Diagnosis } & AML & 4 & 8.5 \\
\hline & T-ALL & 5 & 10.6 \\
\hline & B-ALL & 28 & 59.6 \\
\hline & Lymphoma & 10 & 21.3 \\
\hline
\end{tabular}

Tab. 1. Characteristics of the studied group of parents of children diagnosed with cancer from the necessity to provide care to their child. A comparative analysis of the groups of parents who participated in all the measurements $(t 1, t 2, t 3)$, as well as those who were not subject to full assessment ( $\mathrm{t} 1$ only or $\mathrm{t} 1$ and $\mathrm{t} 2$ ) did not show any statistically significant differences in the terms of parents' age (the Mann-Whitney $U$ test $Z=0.43, p=0.67$ ), their sex $\left(\chi^{2}=1.44, p=0.23\right)$, children's age (the MannWhitney $U$ test $Z=-0.13, p=0.89)$, their sex $\left(\chi^{2}=0.01\right.$, $p=0.93)$, place of residence $\left(\chi^{2}=0.01, p=0.93\right)$, education level $\left(\chi^{2}=2.09, p=0.55\right)$, income per each family member $\left(\chi^{2}=2,99, p=0,39\right)$, number of children under care $\left(\chi^{2}=0.76, p=0.68\right)$.

The parents' age ranged between 21 and 56 years $(M=37.7$; standard deviation, $S D=7.0)$. Among the study participants, $78.7 \%$ (37 individuals) were women, and $21.3 \%$ (10 subjects) were men. In the group of young patients, $55.3 \%$ (26) were girls and $44.7 \%$ (21) were boys. During the assessment of the parents, the children's age ranged between one year and 16 years $(M=7.8 ; S D=4.8)$. Detailed characteristics of the analysed group of parents of children with diagnosed leukaemia or lymphoma are presented in Tab. 1. The study procedure was conducted in the years 2014-2018

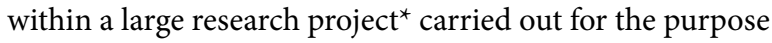
of a doctoral dissertation. The study protocol, the participant information leaflet template as well as the informed consent form were approved by the Bioethics Committee of the Medical University of Lodz (Resolution no. RNN/112/14/KE of $17^{\text {th }}$ June 2014).

An original sociodemographic questionnaire developed by the authors as well as the Impact of Event Scale - Revised were used in the study.

\section{Impact of Event Scale - Revised (IES-R)}

The tool was designed mainly for assessment of PTSD symptoms (clinical diagnosis of PTSD requires a specialised test according to the criteria established under the applicable classification of diseases and mental disorders). It indicates general intensity of posttraumatic stress symptoms as well as of specific symptoms of different posttraumatic stress dimensions (intrusion, avoidance and hyperarousal) (Juczyński and Ogińska-Bulik, 2009). The scale, adjusted to Polish conditions by Juczyński and Ogińska-Bulik, consists of 22 statements which reflect symptoms of stress experienced in the last 7 days (Juczyński and Ogińska-Bulik, 2009). The subject assesses the frequency of symptoms based on a five-degree scale ( 0 - not at all, 1 - a little bit, 2 moderately, 3 - quite a bit, 4 - extremely) with reference to a specific traumatic event (for the purpose of the study, the parents assessed occurrence of posttraumatic stress symptoms with regard to their child's disease). The internal consistency score for the entire scale of the Polish IES-R version is 0.92 , while for the intrusion subscale it is $0.89,0.85$ for

* The project was financed under the statutory research scheme of the Medical University of Lodz (research task no. 502-03/1-155-01/502-14-173). 


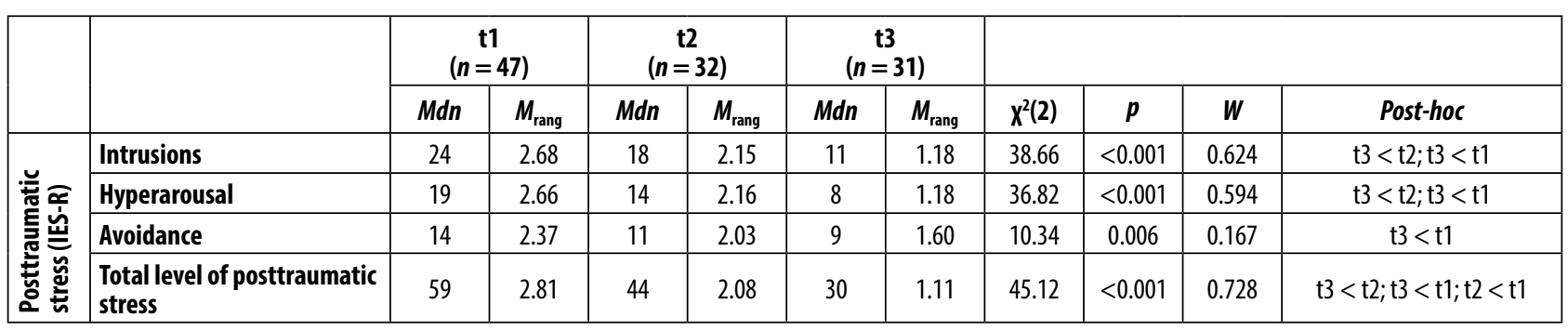

Tab. 2. Intensity of posttraumatic stress at the successive study stages $(t 1, t 2, t 3)$ in parents of children diagnosed with cancer

hyperarousal and 0.78 for avoidance. Whereas, the results of absolute stability coefficients for both the entire scale and the subscales of intrusion, hyperarousal and avoidance are $0.75,0.79,0.76$ and 0.68 , respectively. The validity coefficients also seem to be satisfactory. The criterion-related validity estimated based on correlation of IES-R results with the scores of the General Health Questionnaire (GHQ-28) indicated high relations between the dimensions of anxiety/ sleeplessness (0.46) and functional disorders (0.43) and intrusion with depressive symptoms (0.51).

\section{Sociodemographic questionnaire}

The study was based on an original questionnaire developed by the authors for measurement of sociodemographic data of the parents as well as selected data on the children (age, child's sex, diagnosis, stage of therapy). The questionnaire included questions referring to such variables as age and sex of a parent, his/her education level, professional activity, income, family situation, number of children under care.

\section{Statistical analysis}

In order to test differences between the parents who agreed to take part in the study and those who refused, the MannWhitney $U$ and chi-square $\left(\chi^{2}\right)$ tests were used. Whereas, differences in intensity of posttraumatic stress symptoms presented by the parents depending on a time point following diagnosis were assessed based on the Friedman oneway repeated measure analysis of variance by ranks, i.e. the Friedman test (not fulfilled assumption of normal distribution). The significance level was $p<0.05$.

\section{RESULTS}

The analysis of variance revealed statistically significant differences in the intensity of symptoms depending on a period of time that passed following a child's diagnosis, and the applied post-hoc tests indicated statistically significant differences between specific study stages at which the parents were assessed ( $t 1, t 2, t 3)$. As for the general posttraumatic stress score, significant differences between all the stages of the study were identified $(t 1>t 2, t 1>t 3, t 2>t 3)-$ the most severe symptoms were manifested at stage $t 1$ be observed at stage t3 $\left(M d n=30, M_{\text {rang }}=1.11\right)$. Similarly, the analysis of posttraumatic stress dimensions (intrusion, hyperarousal, avoidance) at particular stages of the study showed decreasing intensity of the symptoms in the subsequent phases $(t 1, t 2, t 3)$. However, it should be emphasised that in the case of the intrusion related to posttraumatic stress, differences in the significance level were related to symptoms at the first ( $\mathrm{t} 1)$ and the third stage ( $\mathrm{t} 3)$ - the intensity at stage $t 1\left(M d n=24, M_{\text {rang }}=2.68\right)$ was higher than at stage $\mathrm{t} 3\left(M d n=11, M_{\text {rang }}=1.18\right)$. There were also differences between the second (t2) and the third stage (t3) the intensity at the second stage $\left(M d n=18, M_{\text {rang }}=2.15\right)$ was higher as compared to the third stage. Similar differences could be observed in the case of hyperarousal dimension (t1: $M d n=19, M_{\text {rang }}=2.66 ; \mathrm{t} 2: M d n=14, M_{\text {rang }}=2.16$; t3: $\left.M d n=8, M_{\text {rang }}=1.18\right)$. Whereas, as for the avoidance dimension, the difference in terms of statistical significance occurred between the first (t1) and the third stage (t3), where intensity of the symptoms in the first phase $\left(M d n=14, M_{\text {rang }}=2.37\right)$ was higher than the intensity of the symptoms in the third phase $\left(M d n=9, M_{\text {rang }}=1.60\right)$. Detailed data are presented in Tab. 2.

\section{DISCUSSION}

The study presents a comparison of intensity of posttraumatic stress symptoms in parents of children with blood cancer at three successive time points following the diagnosis with the assumption that the dynamics of symptoms in both the general aspect and specific individual stress dimensions changes over time. It was assumed that these differences may be conditioned by various experiences of a child, and consequently of a parent, at specific stages of therapy and may involve, among others, requirements resulting from the diagnosis and treatment as well as adaptation associated with them. It should be emphasised that diagnostic and medical procedures applied when diagnosis is established differ from those the child is subject to six months or one year later.

The most intensive symptoms occurred within up to one month following diagnosis (t1). A great severity of psychopathological symptoms manifested by parents at the time of their child's diagnosis is proved by numerous studies (Kazak et al., 2004, 2005; Patiño-Fernández et al., 2008; Santacroce, 2002; Stehl et al., 2009). This period gives rise to 
uncertainty about the final diagnosis, prognosis, therapy procedure and its consequences. At this point, parents experience not only a deep fear for their child's health and life, but also a fear for his/her acceptance of information on the disease and the young patient's response to therapy. Parents may feel aggrieved, embittered, hopeless and have the sense of injustice. Moreover, at this stage they are forced to react quickly, take difficult decisions in a new situation they sometimes cannot understand or accept. Therefore, this stage is different from the others in terms of great anxiety resulting not only from fear for a child's life but also from the necessity to face challenges posed by a completely new and difficult situation. Comparison of symptom intensity in the parents at subsequent study stages after the moment of diagnosis $(t 1, t 2, t 3)$ showed a decrease in the analysed variables over time. This pattern is also confirmed by other studies (e.g. Cernvall et al., 2012; Jurbergs et al., 2009; Landolt et al., 2012; Phipps et al., 2005; Pöder et al., 2008). A decrease in the intensity of posttraumatic stress symptoms over time that passed from the moment of the child's diagnosis may be explained by references to theories illustrating the process of posttraumatic response, e.g. based on the model of adaptation developed by Mardi Horowitz (Horowitz, 1993). The author distinguishes five subsequent stages, i.e. outcry, denial, invasion (intrusion), working through and completion. The first three phases involve intensive processes aimed at integrating traumatic contents into already existing internal schemas. This stage is characterised by initially very strong emotions that are followed by interrelated experiences of denying difficulties and intrusive inflow of emotions, information or compulsive reactions. It is only in the final working through phase that the internal balance is gradually regained, hyperarousal reduces and cognitive schemas are restructured. The last phase reflects a relatively completed processing of traumatic contents and it is associated with the sense of internal integrity. Therefore, it may be concluded that over time that passes from the moment of a child's diagnosis and the acquired cognitive adaptation, the level of posttraumatic stress symptoms experienced by parents decreases.

Parents' gradual adaptation to a critical event being cancer affecting their child, in a period lasting up to one year following the diagnosis, may also be associated with experience of dealing with requirements resulting from such a situation. Unlike at the stage of diagnosis, in the remaining phases parents continue their efforts aimed at adapting themselves to the situation caused by their child's health condition, they are quite familiar with the specific nature of the disease and therapeutic requirements, thus, after some time the situation is no longer new. It is also important that they apply management strategies which at this point may be particularly activated due to strenuous efforts to exert an impact on the situation. It is possible that parents' continuous experience of coping with subsequent challenges posed by their child's therapy itself (intensive therapy, and then treatment aimed at sustaining remission) or control over the child following newly completed intensive therapy regularly improve the parents' adaptation skills.
It is worth emphasizing that statistically significant differences concerning all the studied symptoms were related to the first (t1) and the third (t3) stage only. These differences may be explained by a marked change in the specificity of therapy - treatment and hospitalisation usually becomes considerably less intensive one year after diagnosis. As study results prove, frequent hospital stays, degree of a child's physical disability, behavioural problems are related with parents' adaptation (Klassen et al., 2008; Landolt et al., 2012; Manne et al., 1995). As compared to the initial phase, one year following diagnosis, a young patient's condition may already be relatively stable to an extent which enables the child to his/her routine activities, therefore, fear for the son's or daughter's life may significantly decrease then (Shah and Wayne, 2015). Between the second (t2) and the third stage of the study, the differences were related to all symptoms, except for the avoidance dimension of posttraumatic stress. Similarly, as regards the avoidance dimension, no differences were observed between the first (t1) and the second ( $\mathrm{t} 2$ ) stage of the study. Thus, the intensity of the symptom does not decrease significantly over a period shorter than one year following diagnosis. Avoidance of thoughts, experiences or conversations concerning a child's disease in the initial phase after diagnosis, i.e. a symptom of a posttraumatic response which develops, may bring a great relief protecting parents against fear. Additionally, it was proved that avoidance regarded as a certain type of stress management strategy may perform a useful function in the initial period of coping with stress, unlike in situations where avoidance strategies are also applied in very distant stages of stressful events (Heszen and Sęk, 2007). Moreover, as regards the hyperarousal and intrusion of posttraumatic stress, as in the case of avoidance, no difference between the first (t1) and the second (t2) stage of the study occurred either. The difference, however, is related to the general dimension of posttraumatic stress, which means that its specific dimensions do not decrease so remarkably within six months following diagnosis as compared to the general dimension of this variable. In their study, Norberg et al. (2005) report that the level of intrusion and hyperarousal was higher in parents of children undergoing treatment than in parents of young patients who had already completed therapy. It is worth emphasising that some empirical research suggests a higher frequency of intrusion symptoms among the other dimensions of posttraumatic stress in the group of parents of children suffering from cancer (Manne et al., 1998; Norberg and Boman, 2008; Norberg et al., 2005). Perhaps recurrent thoughts or images associated with a child's disease or therapy play a special role in this group of subjects, e.g. due to a real threat to the child's life or health and these emotions may become weaker with time. The intensive fear at the initial stage of diagnosis and therapy may also justify persistent hyperarousal symptoms as fear is manifested by, among others, symptoms of physiological arousal such as increased heart and/or respiration rate, hypertonia, suppression of gastric acid secretion or weakening of 
the immune system function (Seligman et al., 2003). As it is generally known, hyperarousal is an axial symptom not only in the clinical picture of posttraumatic stress but also in other anxiety disorders (Brown and McNiff, 2009).

\section{CONCLUSIONS}

1. Intensity of posttraumatic stress symptoms in parents of children with blood cancer decrease over time that passed following the diagnosis.

2. Changes in severity of posttraumatic stress symptoms over a year following the diagnosis are characterised by specific dynamics, crucial in terms of psychological intervention planning.

3. The results obtained in the conducted study give grounds for putting forward recommendations that may be useful in psychological diagnosis, psychoeducation and therapy for parents of children with blood cancer. Within a period lasting up to one month following diagnosis, parents should be provided with special psychological support as well as therapeutic measures based on crisis intervention procedure. Moreover, it is important to pay special attention to avoidance symptoms by identifying the role they play in the process of adaptation to the child's disease as well as to their significance in the context of parent's ability to face the disease challenges.

4. It should be remembered that any measures applied within a therapy or support provided to parents have considerable importance for their children and translate into effectiveness of psychological support offered to them.

\section{STUDY LIMITATIONS}

The basic limitation of the study is associated with the uneven number of the subjects at each of the stages $(\mathrm{t} 1=47$, $\mathrm{t} 2=32, \mathrm{t} 3=31$ ). Another limitation is the fact that the study was conducted within one research centre, which means that caution should be exercised when attempting to generalize the results. Additionally, the use of a self-description questionnaire for the assessment of intensity of posttraumatic stress symptoms incurs a risk of uncertainty (unreliability) of measurement.

\section{Conflict of interest}

The authors declare no financial or personal relations with other persons or organisations that could have a negative impact on the contents of the article or claim any rights hereto.

\section{References}

Balcerska A, Adamkiewicz-Drożyńska E, Stefanowicz J: Stany zagrożenia życia w onkologii dziecięcej. In: Chybicka A, Sawicz-Birkowska K (eds.): Onkologia i hematologia dziecięca. Vol. 1, Wydawnictwo Lekarskie PZWL, Warszawa 2008: 551-567.

Baran J: Zastosowanie koncepcji stresu traumatycznego w badaniach dzieci z chorobami nowotworowymi i ich rodziców. Psychoonkologia 2009; 1-2: 28-32.

Brown TA, McNiff J: Specificity of autonomic arousal to DSM-IV panic disorder and posttraumatic stress disorder. Behav Res Ther 2009; 47: 487-493.

Cernvall M, Alaie I, von Essen L: The factor structure of traumatic stress in parents of children with cancer: a longitudinal analysis. J Pediatr Psychol 2012; 37: 448-457.

Deręgowska J: Dziecko z chorobą nowotworową w rodzinie. Diagnoza - wsparcie. Wydawnictwo Naukowe Wyższej Szkoły Nauk Humanistycznych i Dziennikarstwa, Poznań 2010.

Fisak B Jr, Grills-Taquechel AE: Parental modeling, reinforcement, and information transfer: Risk factors in the development of child anxiety? Clin Child Fam Psychol Rev 2007; 10: 213-231.

Garber J, Cole DA: Intergenerational transmission of depression: a launch and grow model of change across adolescence. Dev Psychopathol 2010; 22: 819-830.

Heszen I, Sęk H: Psychologia zdrowia. Wydawnictwo Naukowe PWN, Warszawa 2007.

Horowitz MJ: Stress-response syndromes: a review of posttraumatic and adjustment disorders. In: Wilson JP, Raphael B (eds.): International Handbook of Traumatic Stress Syndromes. Plenum Press, New York 1993: 49-60.

Juczyński Z, Ogińska-Bulik N: Pomiar zaburzeń po stresie traumatycznym - polska wersja Zrewidowanej Skali Wpływu Zdarzeń. Psychiatria 2009; 6: 15-25.

Jurbergs N, Long A, Ticona L et al.: Symptoms of posttraumatic stress in parents of children with cancer: are they elevated relative to parents of healthy children? J Pediatr Psychol 2009; 34: 4-13.

Kazak AE, Alderfer M, Rourke MT et al.: Posttraumatic stress disorder (PTSD) and posttraumatic stress symptoms (PTSS) in families of adolescent childhood cancer survivors. J Pediatr Psychol 2004; 29: 211-219.

Kazak AE, Boeving CA, Alderfer MA et al.: Posttraumatic stress symptoms during treatment in parents of children with cancer. J Clin Oncol 2005; 23: 7405-7410.

Klassen AF, Klaassen R, Dix D et al.: Impact of caring for a child with cancer on parents' health-related quality of life. J Clin Oncol 2008; 26: 5884-5889.

Kowalczyk JR: Epidemiologia nowotworów złośliwych u dzieci. In: Chybicka A, Sawicz-Birkowska K (eds.): Onkologia i hematologia dziecięca. Vol. 1, Wydawnictwo Lekarskie PZWL, Warszawa 2008: 3-7.

Krawczuk-Rybak M (ed.): Kompendium onkologii dziecięcej dla studentów VI roku Wydziału Lekarskiego UMB. Białystok 2011. Available from: http://www.umb.edu.pl/photo/pliki/WL_jednostki/ klinika_onkologii_i_hematologii_dzieciecej/kompendium_onkologii_dzieciecej_aktualizacja_2013.doc [cited: 16 August 2018].

Landolt MA, Vollrath M, Ribi K et al.: Incidence and associations of parental and child posttraumatic stress symptoms in pediatric patients. J Child Psychol Psychiatry 2003; 44: 1199-1207.

Landolt MA, Ystrom E, Sennhauser FH et al.: The mutual prospective influence of child and parental post-traumatic stress symptoms in pediatric patients. J Child Psychol Psychiatry 2012; 53: 767-774.

Manne SL, Du Hamel K, Gallelli K et al.: Posttraumatic stress disorder among mothers of pediatric cancer survivors: diagnosis, comorbidity, and utility of the PTSD checklist as a screening instrument. J Pediatr Psychol 1998; 23: 357-366.

Manne SL, Lesanics D, Meyers P et al.: Predictors of depressive symptomatology among parents of newly diagnosed children with cancer. J Pediatr Psychol 1995; 20: 491-510. 
Meder J: Rak głównym zabójcą ludzi w XXI wieku. Narodowy Program Zwalczania Chorób Nowotworowych. In: Potrykowska A, Strzelecki Z, Szymborski J (eds.): Zachorowalność i umieralność na nowotwory a sytuacja demograficzna Polski. Rządowa Rada Ludnościowa, Warszawa 2014: 50-85.

Norberg AL, Boman KK: Parent distress in childhood cancer: a comparative evaluation of posttraumatic stress symptoms, depression and anxiety. Acta Oncol 2008; 47: 267-274.

Norberg LA, Lindblad F, Boman KK: Parental traumatic stress during and after paediatric cancer treatment. Acta Oncol 2005; 44: 382-388.

Patiño-Fernández AM, Pai ALH, Alderfer M et al.: Acute stress in parents of children newly diagnosed with cancer. Pediatr Blood Cancer 2008; 50: 289-292.

Phipps S, Long A, Hudson M et al.: Symptoms of post-traumatic stress in children with cancer and their parents: effects of informant and time from diagnosis. Pediatr Blood Cancer 2005; 45: 952-959.

Pöder U, Ljungman G, von Essen L: Posttraumatic stress disorder among parents of children on cancer treatment: a longitudinal study. Psychooncology 2008; 17: 430-437.

Rodriguez EM, Dunn MJ, Zuckerman T et al.: Cancer-related sources of stress for children with cancer and their parents. J Pediatr Psychol 2012; 37: 185-197.

Santacroce S: Uncertainty, anxiety, and symptoms of posttraumatic stress in parents of children recently diagnosed with cancer. J Pediatr Oncol Nurs 2002; 19: 104-111.

Seligman MEP, Walker EF, Rosenhan DL: Psychopatologia. Zysk i S-ka, Poznań 2003.

Shah NN, Wayne AS: Leukemias and lymphomas. In: Wiener LS, Pao M, Kazak AE et al. (eds.): Pediatric Psycho-Oncology: A Quick Reference on the Psychosocial Dimensions of Cancer Symptom Management. $2^{\text {nd }}$ ed., Oxford University Press, New York 2015: 3-10.
Solecka D: Dziecko chore somatycznie. In: Bętkowska-Korpała B, Gierowski JK (eds.): Psychologia lekarska w leczeniu chorych somatycznie. Wydawnictwo Uniwersytetu Jagiellońskiego, Kraków 2007: 17-34.

Steele RG, Dreyer ML, Phipps S: Patterns of maternal distress among children with cancer and their association with child emotional and somatic distress. J Pediatr Psychol 2004; 29: 507-517.

Stehl ML, Kazak AE, Alderfer MA et al.: Conducting a randomized clinical trial of an psychological intervention for parents/caregivers of children with cancer shortly after diagnosis. J Pediatr Psychol 2009; 34: 803-816.

Stolarska M, Młynarski W: Rola opieki paliatywnej w onkologii dziecięcej. In: Korzeniewska-Eksterowicz A, Młynarski W (eds.): Pediatryczna opieka paliatywna. Uniwersytet Medyczny w Łodzi, Łódź 2011: 240-261.

Stuber ML, Shemesh E, Saxe GN: Posttraumatic stress responses in children with life-threatening illnesses. Child Adolesc Psychiatr Clin N Am 2003; 12: 195-209.

Szymborski J, Didkowska J, Wojciechowska U: Nowotwory złośliwe u dzieci i młodzieży w Polsce. In: Potrykowska A, Strzelecki Z, Szymborski J et al. (eds.): Zachorowalność i umieralność na nowotwory a sytuacja demograficzna Polski. Rządowa Rada Ludnościowa, Warszawa 2014: 117-146.

Vrijmoet-Wiersma CMJ, van Klink JMM, Kolk AM et al.: Assessment of parental psychological stress in pediatric cancer: a review. J Pediatr Psychol 2008; 33: 694-706. 